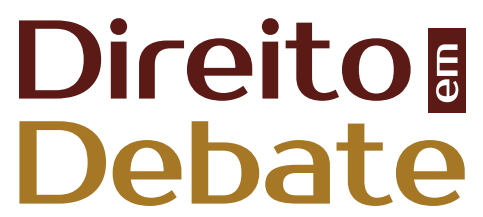

Revista do Departamento de Ciências Jurídicas e Sociais da Unijuí Editora Unijuí - Ano XXX - n. 56 - jul./dez. 2021 - ISSN 2176-6622

\title{
REGULAÇÃO AMBIENTAL NO DIREITO INTERNACIONAL DO INVESTIMENTO
}

\author{
http://dx.doi.org/10.21527/2176-6622.2021.56.9037
}

Recebido em: 16/5/2019

Modificações solicitadas em: 28/5/2020

Aceito em: 10/11/2020

Natália Paulino Bonnomi

Universidade Federal de Pernambuco - UFPE. Av. Prof. Moraes Rego, 1.235 - Cidade Universitária. Recife/PE, Brasil. CEP 50670-901. http://lattes.cnpq.br/0292379684537867. https://orcid.org/0000-0001-7680-4169. nataliapbmi@gmail.com

\section{RESUMO}

O presente artigo aborda a relação entre a regulação legítima ambiental e a expropriação indireta segundo as disposições contidas nos acordos internacionais de investimento. Para tanto serão analisados os principais parâmetros utilizados nos acordos internacionais a fim de distinguir uma medida de regulação ambiental legítima de uma medida expropriatória, apta a gerar o dever de compensação do investidor por parte do Estado receptor. A pesquisa desenvolvida neste artigo explora a contribuição da doutrina e de instrumentos internacionais sobre o tema. Conclui-se que não há um entendimento uniforme nos acordos internacionais de investimento sobre os limites entre uma medida regulatória ambiental e uma medida expropriatória, o que acaba por ensejar uma inconsistência sobre o assunto no âmbito do Direito Internacional do Investimento.

Palavras-chave: Investimento; regulação; meio ambiente; expropriação.

\section{ENVIRONMENTAL REGULATION IN THE INTERNATIONAL INVESTMENT LAW}

\section{ABSTRACT}

The present article deals with the relationship between legitimate environmental regulation and indirect expropriation according to the provisions of the international investment agreements. In order to do that, the article will carry out an analysis of the main parameters adopted in international agreements to distinguish a measure of legitimate environmental regulation from a measure of expropriation, which entails the obligation of the host State to compensate the foreign investor. The research carried out in this article explores the contribution from literature and international instruments over the topic. It is concluded that there is no uniform understanding in the international investment agreements about the limits to distinguish a environmental regulatory measure from an expropriatory measure, what results in some inconsistency over the matter in the International Investment Law field.

Keywords: Investment; regulation; environment; expropriation. 


\section{INTRODUÇÃO}

Ao optar por investir em determinado país, o investidor estrangeiro submete-se ao seu ordenamento jurídico interno e ao risco de eventuais modificações políticas ou financeiras no Estado receptor. Para minimizar tais riscos, os direitos do investidor são protegidos pelo Estado receptor nos termos dos acordos e contratos de investimento aplicáveis, em geral conforme padrões internacionais mínimos de tratamento.

Embora, no entanto, seja necessário garantir que os interesses do investidor sejam protegidos, os acordos e os contratos internacionais de investimento também devem buscar assegurar o policy space do Estado receptor, ou seja, seu espaço para instituição de políticas públicas com o objetivo de se desenvolver e de garantir o interesse público. As medidas de regulação doméstica tomadas pelo Estado receptor no exercício de sua soberania são reflexo do poder de polícia estatal (police powers). 0 exercício desse poder permite que 0 Estado proteja interesses públicos tidos como essenciais contra determinados danos, que podem ser provenientes da atividade do investidor.

Observa-se, portanto, que os direitos conferidos ao investidor não são absolutos, visto que devem respeitar as normas vigentes no Estado receptor editadas para proteger o interesse público. Logo, caso a atuação do investidor seja considerada lesiva ao interesse público do Estado receptor, o Direito Internacional tem reconhecido seu direito a adotar medidas regulatórias que afetem negativamente o investimento. Os acordos internacionais, de maneira geral, concedem esse direito ao Estado receptor, porém exigem que as medidas tidas como expropriatórias preencham certos requisitos, entre eles o de compensação em favor do investidor.

Nesse contexto, há, de um lado, o direito do investidor de usufruir do proveito econômico de seu investimento sem a interferência estatal, e, de outro lado, a necessidade de o Estado receptor assegurar a adoção de políticas públicas que visem ao bem-estar social. Por esta razão, os acordos internacionais de investimento, bem como a doutrina especializada, apontam que o exercício legítimo do Estado receptor de seu poder de regulação, ainda que produzisse um impacto negativo no investimento, configuraria uma medida regulatória, distinta de uma expropriação, que gera o dever de compensação ao investidor estrangeiro.

Diante disso, o principal objetivo do artigo é identificar quando uma medida regulatória do Estado receptor, no caso deste estudo, destinada à proteção do meio ambiente, configura uma regulação legítima, proveniente do interesse público estatal, e em que hipóteses constitui uma medida expropriatória, que acaba por privar o investidor do aproveitamento econômico de seu empreendimento.

As perguntas levantadas pela pesquisa são as seguintes: 1) em que hipóteses a atuação estatal que interfere no investimento estrangeiro será considerada uma expropriação indireta ou uma regulação legítima?; 2) a regulação estatal, ainda que legítima, enseja o dever de compensação ao investidor por parte do Estado receptor?; 3) a efetivação de políticas públicas ambientais pode ser considerada uma regulação legítima?

A fim de responder a estes questionamentos, serão examinados os critérios adotados nos acordos internacionais de investimento para reconhecer uma medida como regulatória ou expropriatória, assim como a interpretação conferida pela literatura a esses parâmetros. Tais critérios podem ser encontrados na larga maioria dos acordos de investimento, os quais tiveram como norte o Acordo de Livre Comércio da América do Norte (Nafta), e têm sido objeto de estudo da doutrina especializada no tema de investimento estrangeiro. Além disso, para melhor elucidar a aplicação desses critérios à regulação ambiental, são citadas algumas disputas dirimidas em Cortes Arbitrais, as quais foram selecionadas pelo fato de enfrentarem a controvérsia acerca do reconhecimento ou não de uma medida regulatória ambiental como uma medida de expropriação indireta.

\section{O CONCEITO DE EXPROPRIAÇÃO NO DIREITO INTERNACIONAL DO INVESTIMENTO}

Existem situações em que a atuação regulatória estatal prejudica a atividade exercida pelo investidor de modo a dificultar ou, até mesmo, a inviabilizar o investimento. É possível, por exemplo, que o Estado receptor proíba a circulação em seu território de determinado produto cujo malefício à saúde humana foi comprovado por órgão competente, o qual constitui o único objeto de produção de um investidor estrangeiro instalado nesse país. Percebe-se que, ainda que tal medida estatal impossibilite a atuação do investidor, esta atende a um interesse público de proteção à saúde dos consumidores. 
No caso citado, verifica-se que a determinação do Estado receptor pode ensejar uma controvérsia acerca do caráter expropriatório da medida, uma vez que esta inviabilizaria a execução do investimento de tal maneira que equivaleria a retirar o direito de propriedade do investidor. Nesse ponto, é necessário discorrer sobre o conceito de expropriação e as suas modalidades.

Entendia-se por expropriação o ato estatal de destituir o investidor do seu título de propriedade, conceito este que tornava fácil verificar a configuração ou não de uma medida expropriatória no caso concreto. No período posterior às descolonizações, a retirada do direito de propriedade do investidor tornou-se comum em razão do objetivo dos Estados de reaver o controle sobre a sua economia por meio da nacionalização das empresas estrangeiras. Os países em desenvolvimento efetuaram mudanças no processo de entrada do investimento estrangeiro, que ocorria principalmente na forma de joint ventures incorporadas ao Estado receptor, a fim de obter um maior controle administrativo sobre o investimento (SORNARAJAH, 2010, p. 363).

Essa expropriação direta, no entanto, que retira o título formal de propriedade do investidor, é hoje rara no cenário internacional. Atualmente a interferência do Estado receptor no direito de propriedade do investidor estrangeiro tem envolvido vários tipos de regulação, voltadas de forma especial para atender seus objetivos de desenvolvimento econômico e garantir a proteção das pessoas e do meio ambiente. Diante disso, o regime internacional de proteção ao investimento teve de se adaptar a essas novas formas de intervenção estatal na propriedade do investidor estrangeiro (SORNARAJAH, 2010, p. 363).

Nesse sentido, podem ser identificados três tipos de expropriação nos acordos internacionais de investimento: expropriação direta, expropriação indireta e medida equivalente à expropriação. Em verdade, embora expresso em diversos acordos de investimento, o terceiro tipo não configura uma outra espécie de expropriação, mas sim uma medida que seria similar a uma expropriação direta ou indireta (SORNARAJAH, 2010, p. 363).

Faz-se necessário, portanto, distinguir a expropriação direta da expropriação indireta. A expropriação direta transfere o título de propriedade do investidor para o Estado ou para um terceiro e é raramente utilizada pelo Estado receptor em razão da má reputação que tal medida traria ao Estado em termos de atração de investimento estrangeiro. Já a expropriação indireta, que consiste na adoção de medidas com objetivos regulatórios legítimos, não retira o direito de propriedade do investidor formalmente, mas o priva da possibilidade de empregar o investimento de forma significativa, o que, em termos práticos, seria semelhante a expropriá-lo (DOLZER; SCHREUER, 2008, p. 92).

Dentro do conceito de expropriação indireta encontram-se a expropriação creeping, que se caracteriza pela retirada do direito de propriedade do investidor de forma paulatina, e a expropriação regulatória, que, quando motivada por um interesse público e reconhecida como regulação legítima, em princípio não está sujeita a pagamento de compensação (RIBEIRO, 2014, p. 145-146).

A proteção do investidor contra a expropriação é matéria recorrente nos acordos internacionais de investimento. O Nafta, por exemplo, em seu artigo 1.110, veda a expropriação direta ou indireta do investimento ou a adoção de medida equivalente à expropriação, exceto se decorrente de um interesse público, de forma não discriminatória, de acordo com o devido processo legal e sob pagamento de compensação ao investidor. Tais requisitos encontram-se presentes na larga maioria dos acordos de investimento para caracterizar uma expropriação legítima, inclusive no texto do USMCA, que virá a substituir o Nafta.

No mesmo sentido dispõe o Modelo de BIT dos Estados Unidos, no Artigo 6ㅇ da sua versão de 2012, que estabelece, em termos semelhantes aos do Nafta, que a compensação deve ser pronta, adequada e efetiva. O método de pagamento da compensação deve obedecer aos seguintes requisitos: deve ser paga sem atraso; seu valor deve ser equivalente ao valor justo de mercado aferido na data da expropriação; não deve refletir a alteração negativa no valor de mercado em razão de conhecimento da intenção de expropriar com antecedência à data da expropriação e deve ser completamente liquidável e livremente transferível.

O Anexo B do Modelo de BIT estadunidense trata das duas hipóteses de expropriação: a primeira, a expropriação direta, quando há transferência formal do título de propriedade do investidor ou sua retirada de forma definitiva; e a segunda, a expropriação indireta, que ocorre por meio de atos estatais com efeitos equivalentes aos da expropriação direta, embora sem haver a retirada formal do direito de propriedade do 
investidor. A expropriação direta, por resultar na perda do direito de propriedade do investidor por retirada formal do Estado, é fácil de ser visualizada.

A configuração da expropriação indireta, por sua vez, segundo o referido Anexo, depende da análise do caso concreto, baseada em fatos, e deverá observar, entre outros fatores: o impacto econômico da ação governamental (com a ressalva de que o efeito negativo no valor econômico de um investimento não constitui, por si só, a ocorrência de uma expropriação indireta); a extensão da interferência da ação governamental nas expectativas distintas e razoáveis do investimento e o caráter da ação governamental. Tais critérios são essenciais para se distinguir uma medida regulatória de uma medida expropriatória.

\section{EXPROPRIAÇÃO INDIRETA VS. REGULAÇÃO LEGÍTIMA}

Antes de se determinar se a expropriação em questão é legítima, deve-se avaliar, em primeiro lugar, se a medida é de fato expropriatória, como observado anteriormente. Em segundo lugar, após esse exame, passa-se à análise do preenchimento ou não dos requisitos para uma expropriação legítima, que normalmente dizem respeito ao interesse público, à não discriminação, ao devido processo legal e ao pagamento de compensação (UNCTAD..., 2012, p. 27).

O requisito referente ao interesse público é reconhecido na maioria dos ordenamentos jurídicos e representa uma regra de Direito Internacional. A retirada da propriedade do investidor deve estar fundamentada na busca por um interesse público legítimo, em oposição a um interesse meramente privado ou ilícito (UNCTAD..., 2012, p. 28-29).

Já o requisito da não discriminação restará violado se a expropriação estiver fundamentada na nacionalidade do investidor. Vale ressaltar que o tratamento diferenciado não necessariamente enseja discriminação. Uma expropriação somente será considerada discriminatória se estiver baseada em, relacionada a ou motivada pela origem do investidor (UNCTAD..., 2012, p. 34).

A exigência de um devido processo legal será satisfeita se reunidas as seguintes condições: cumprimento dos procedimentos previstos na legislação interna e nas regras fundamentais de Direito Internacional pertinentes à matéria; oportunidade conferida ao investidor para revisar a medida perante um órgão independente e imparcial e não arbitrariedade. A necessidade de prévia notificação ao investidor não compõe, em princípio, o requisito do devido processo legal, especialmente quando a medida expropriatória é adotada em circunstâncias de iminente necessidade ou emergência (UNCTAD..., 2012, p. 36, 40).

Finalmente, o requisito da compensação é uma das questões mais controversas acerca do tema de investimento. A tendência presente nos acordos internacionais de investimento é da adoção da fórmula Hull, que exige a compensação pronta, adequada e efetiva, bem como baseada no valor de mercado, de forma rápida e em moeda conversível (FONSECA, 2010, p. 118). A compensação será considerada pronta se paga sem atraso; adequada quando compatível com o valor de mercado, também chamado de valor justo, valor real, valor genuíno ou valor econômico real, e efetiva quando paga em moeda conversível (UNCTAD..., 2012, p. 40).

Sendo assim, a expropriação indireta estará configurada quando presente, em primeiro lugar, o caráter expropriatório da medida estatal, a ser determinado na análise do caso concreto, baseada em fatos, de acordo com os parâmetros de impacto econômico, interferência na expectativa do investidor e caráter da medida.

Em segundo lugar, para que uma medida tida como expropriatória seja julgada como legítima, requer-se a reunião dos requisitos de interesse público, não discriminação, devido processo legal e compensação. Desse modo, garante-se o direito do Estado receptor de exercer seu poder de regulação, inclusive quando tais medidas ponham em xeque a atividade do investidor estrangeiro, dada a necessidade de se proteger a saúde humana, o meio ambiente ou qualquer outro interesse público relevante.

A questão que tem gerado controvérsia na interpretação dos acordos internacionais de investimento acerca desse tema diz respeito aos limites impostos ao Estado receptor no exercício do direito de regulação, no sentido de determinar o caráter expropriatório de uma medida regulatória. A fim de delimitar os aspectos polêmicos dessa matéria, devem-se apresentar as discussões acerca das seguintes indagações: 1) Em que hipóteses a atuação estatal que interfere no investimento estrangeiro será considerada uma expropriação indireta ou uma regulação legítima? 2) A regulação estatal, ainda que legítima, enseja o dever de compensação ao 
investidor por parte do Estado receptor? 3) A instituição de políticas públicas ambientais pode ser considerada uma regulação legítima?

Em princípio, passa-se a analisar em que situação se está diante de uma medida de expropriação indireta. Posteriormente, será discutido o efeito de uma regulação legítima no que concerne à obrigação do Estado receptor de compensar o investidor. Por fim, na última seção deste artigo será avaliado se uma medida estatal direcionada à proteção ambiental será considerada expropriatória ou fruto de uma regulação legítima.

O primeiro critério para se identificar uma expropriação é o impacto econômico da medida, caracterizado pelo seu efeito destrutivo e duradouro sobre o valor econômico do investimento e o seu benefício para o investidor. Tal parâmetro deve ser estudado com cautela, uma vez que grande parte dos acordos de investimento têm feito a ressalva de que o mero fato de a medida ter um efeito negativo no valor econômico do investimento não implica necessariamente a configuração de uma expropriação indireta, devendo ser considerados a natureza e o caráter da medida (UNCTAD..., 2012, p. 63).

Essa ressalva colide com a doutrina denominada de sole effects, que afirma ser o impacto da medida o critério necessário e suficiente para caracterizar uma expropriação, sem levar em conta a sua natureza e o seu objetivo. Para que haja uma expropriação indireta, os efeitos da medida devem, portanto, equivaler aos de uma expropriação direta, ou seja, tornar inviável o direito de propriedade do investidor (UNCTAD..., 2012, p. 63).

Sendo assim, para que o critério de impacto econômico esteja preenchido, é necessário que a medida resulte na perda, ou quase perda, do valor econômico do investimento. $O$ impacto da medida, apto a ensejar a expropriação indireta, pode não estar relacionado à perda do valor econômico do investimento, mas sim à perda do controle por parte do investidor, impedindo-o de usufruir do investimento. Além disso, seja o impacto da medida relativo ao valor econômico do investimento ou ao controle do investidor uma medida normalmente é considerada expropriatória quanto tal impacto é definitivo e permanente (UNCTAD..., 2012, p. 65-69).

É possível, ainda, visualizar a expropriação indireta por outro aspecto, que diz respeito à interferência da medida na expectativa legítima do investidor. Sabe-se que, ao decidir investir em determinado país, a empresa cria uma expectativa em torno do regime regulatório aplicável à sua atividade. $O$ investidor espera que o arcabouço normativo vigente no Estado receptor no momento do investimento seja mantido estável por um longo tempo, ainda que eventuais mudanças se encontrem na sua esfera de previsibilidade. O problema ocorre não pela regulação em si, haja vista o investidor já se encontrar preparado para isso, mas sim quando a regulação é inesperada e excessiva (KOLO; WÄLDE, 2001, p. 819).

Embora haja entendimento de que se considera legítima a expectativa do investidor baseada em garantias implícitas e presunções, há preferência pelo entendimento de que darão ensejo a expectativas legítimas apenas os compromissos específicos e explícitos do Estado receptor no sentido de não alterar seu regime regulatório. Vale salientar que tal critério, por si só, não é suficiente para demonstrar uma expropriação indireta, devendo estar combinado com o impacto ou o caráter da medida (UNCTAD..., 2012, p. 75-76).

A tendência é que se reconheça o compromisso específico firmado pelo Estado no sentido de não alterar seu regime regulatório como um indicativo de que a medida regulatória constitui expropriação. A justificativa para tal posicionamento é que, tendo em vista a excepcionalidade de o Estado renunciar ao exercício do seu poder regulatório, faz-se necessário que essa renúncia esteja expressa em um compromisso inequívoco. Um exemplo de compromisso específico garantido pelo Estado receptor é a inserção de uma cláusula de estabilização no contrato de investimento de modo a assegurar a estabilidade do seu regime regulatório (POTESTÀ, 2012, p. 31).

Além de garantias específicas concedidas pelo Estado receptor, também se tem considerado, na análise da legitimidade das expectativas do investidor, as características do Estado em termos do ambiente para o investimento. É fácil visualizar que as expectativas de um investidor quanto à segurança de seu investimento variam de acordo com o grau de desenvolvimento do Estado receptor, bem como de questões peculiares de determinados setores econômicos (POTESTÀ, 2012, p. 36).

Desse modo, a fim de verificar se houve ou não expropriação em virtude da quebra de uma expectativa legítima do investidor, avalia-se no caso concreto se, diante do contexto da aplicação do investimento, havia ou não a previsibilidade por parte do investidor de alteração do regime regulatório no Estado receptor. Caso 
se entenda que o investidor, dentro de sua esfera de diligência, poderia ter previsto a mudança no regime regulatório, torna-se insustentável o argumento da ocorrência de expropriação por esse motivo (POTESTÀ, 2012, p. 38).

Por fim, para verificar a ocorrência de uma expropriação indireta, também deve-se levar em consideração a natureza, o objetivo e o caráter da medida, especialmente porque esses elementos ajudam a distinguir entre uma expropriação indireta e uma medida regulatória válida, não sujeita, em princípio, ao pagamento de compensação ao investidor (UNCTAD..., 2012, p. 76). Quando se trata da natureza da medida, refere-se à boa-fé presente ou não no ato de regulação. Já o objetivo diz respeito ao propósito genuíno da medida de buscar ou não um interesse público legítimo. Finalmente, o caráter da medida envolve questões ligadas à não discriminação, devido processo e proporcionalidade (UNCTAD..., 2012, p. 78).

A partir do parâmetro da natureza, do objetivo e do caráter da medida estatal, pode-se estabelecer que tipo de medida é considerada meramente regulatória, que não estaria suscetível a gerar a obrigação de compensação ao investidor estrangeiro, e que tipo configura uma medida expropriatória, que demanda o pagamento de compensação em benefício do investidor.

Deve-se salientar que há um posicionamento isolado que entende que esse parâmetro nem sempre justifica uma regulação. Por exemplo, no caso Santa Elena vs. Costa Rica, os árbitros entenderam que assim como qualquer outra medida estatal que vise ao estabelecimento de uma política pública, uma medida voltada à proteção do meio ambiente também enseja a obrigação do Estado receptor de efetuar o pagamento de compensação em favor do investidor que teve seu investimento expropriado. ${ }^{1}$

O parâmetro da natureza, do objetivo e do caráter da medida estatal tem-se socorrido, ainda, da teoria dos police powers para fundamentar a existência de uma distinção entre uma regulação legítima e uma medida expropriatória, passível de compensação. Segundo Newcombe, a expressão police powers pode ser compreendida, em um sentido mais amplo, como toda forma de regulação doméstica proveniente do exercício da soberania estatal. Em uma interpretação mais restrita, contudo, a teoria refere-se às medidas que justificam a atuação estatal e que, em outras situações, configurariam expropriação (NEWCOMBE, 2005, p. 20).

A dificuldade centra-se em definir quais medidas regulatórias são justificáveis e, portanto, não geram obrigação de compensar o investidor prejudicado. $O$ exemplo citado no início do artigo, referente à proibição de circulação de um produto prejudicial à saúde humana, parece ser um caso de regulação estatal legítima, haja vista fundamentar-se em um interesse público relevante, qual seja, a saúde dos consumidores.

Ao se analisar os acordos internacionais de investimento é possível verificar que o ato de regulação normalmente não configura uma medida expropriatória. Isso porque, como já exposto, o mero fato de a medida regulatória ocasionar um efeito negativo no investimento não é suficiente para se estar diante de uma expropriação. Sendo assim, os acordos de investimento têm reconhecido que a regulação legítima, em regra, não constitui expropriação, e, portanto, não enseja o dever do Estado de compensar o investidor (NEWCOMBE, 2005, p. 22).

Esse entendimento decorre, por exemplo, da Seção 712, Comentário (g), do Restatement Third of The Foreign Relations Law of the United States, ${ }^{2}$ que isenta o Estado de responsabilidade pela perda de propriedade ou outro prejuízo econômico resultante da atuação estatal dotada de boa-fé, seja de tributação, regulação, confisco por crime ou outra medida similar decorrente do poder de polícia do Estado. O Modelo de BIT estadunidense também corrobora essa interpretação ao dispor, no Artigo 4으 (b) do seu Anexo $B$, que, exceto em situações excepcionais, medidas regulatórias não discriminatórias adotadas pelo Estado e destinadas a proteger o interesse público, como a saúde pública, a segurança e o meio ambiente, não constituem expropriação indireta. Nesse sentido posicionam-se a Convenção sobre Responsabilidade Internacional dos Estados por Prejuízos a Estrangeiros de 1961 (Harvard Draft) e a Convenção da Agência Multilateral de Garantia de

Parágrafos 71-72 da decisão final da disputa disponível em: <https://www.italaw.com/sites/default/files/case-documents/italaw6340. pdf>. Acesso em 4 dez. 2018.

2 Os Restatements são tratados elaborados por uma entidade privada, o American Law Institute, que abordam determinados assuntos do Direito para nortear a atuação dos juristas. 
Investimentos (Miga) (UNCTAD..., 2012, p. 82-83). Tal dispositivo também se faz presente no Artigo 3o (b) do Anexo 9-B do texto do Tratado da Parceria Transpacífico (TPP).

Embora os acordos não tenham descrito em que hipóteses excepcionais as medidas regulatórias não estariam caracterizadas como expropriação indireta, um texto provisório do Acordo de Parceria Transatlântica de Comércio e Investimento (TTIP) estabelece que essas situações raras ocorreriam quando o impacto da medida estatal fosse tão grave em virtude do seu propósito que esta fosse considerada manifestamente excessiva. Embora o Artigo 3ㅇ do Anexo I-Expropriação faça parte de um texto ainda em processo de negociação, é importante que se vislumbre um possivel entendimento acerca dessa questão.

Ressalta-se que a Conferência da Nações Unidas para o Comércio e Desenvolvimento (Unctad) tem mapeado os esforços empreendidos pelos Estados no sentido de estabelecer critérios acerca da expropriação indireta nos acordos internacionais de investimento celebrados. A Unctad informa diversas maneiras encontradas em acordos internacionais de investimento a fim de fornecer parâmetros para se visualizar uma expropriação indireta, tais como: 1) o impacto econômico da medida; 2) a extensão da interferência estatal em expectativas legítimas do investidor; 3 ) o caráter da medida estatal (não discriminatória e proporcional); 4) a definição de medidas não consideradas expropriatórias (por exemplo, medidas não discriminatórias, com base em boa-fé e com objetivos públicos legítimos) (UNCTAD..., 2018, p. 37-38).

Sendo assim, o regime internacional de investimento tem levado em consideração o objetivo e o caráter da medida como relevantes para determinar se a medida regulatória assume a feição de expropriação e, logo, se é passível ou não de compensação. Criou-se um entendimento de que uma medida regulatória adotada com base na boa-fé, sem discriminação e de aplicação geral, raramente seria caracterizada como expropriação. Assim sendo, dificilmente um tribunal condenaria o Estado receptor ao pagamento de compensação em virtude da adoção de uma medida regulatória que se justificaria como necessária para o desempenho da obrigação estatal de proteger a saúde pública, a segurança e o bem-estar (JACINTO; MOLOO, 2011, p 15).

\section{LEGITIMIDADE DA REGULAÇÃO AMBIENTAL}

É fundamental que se discorra, a fim de responder ao último questionamento colocado no tópico anterior, sobre que tipos de medidas de regulação seriam consideradas legítimas, e verificar se as medidas de regulação ambiental ${ }^{3}$ encontram-se nessa categoria. Essa análise é essencial para o estudo, haja vista o importante efeito que decorre dessa adequação, qual seja, a isenção de responsabilidade do Estado em compensar o investidor por eventual prejuízo causado a ele.

Deve-se frisar que, embora alguns acordos internacionais de investimento, como mencionado no tópico anterior, tendam a permitir que determinadas medidas estatais não sejam consideradas expropriatórias, conforme os já mencionados critérios, não há clareza quanto à configuração da legitimidade do objetivo perseguido pela medida regulatória. Diante disso, faz-se necessário analisar em que circunstâncias uma medida de regulação ambiental é considerada legítima, o que afastaria seu caráter expropriatório.

Os acordos internacionais de investimento e os tribunais têm reconhecido o exercício legítimo do poder de polícia do Estado receptor, e, de modo geral, a justificativa para o não pagamento da compensação, em dois grupos de situações: a) medidas regulatórias para garantir a ordem pública e a moralidade e b) medidas regulatórias para proteger a saúde humana e o meio ambiente. Tornou-se comum nos acordos de investimento, ainda, a tributação como medida de regulação legítima em princípio (NEWCOMBE, 2005, p. 23).

O primeiro grupo compreende, entre outros tipos de medidas, o confisco da propriedade quando proveniente de atividade criminal, como contrabando ou tráfico de drogas, utilizado como uma forma de o Estado fazer cumprir suas leis. É evidente que, nessas hipóteses, não há dever do Estado de compensar, uma vez que, normalmente, os sistemas legais locais nem reconhecem o direito de propriedade fundado em atividade ilegal. O confisco de propriedade sem pagamento de compensação também pode ocorrer em razão do não

\footnotetext{
Neste artigo, regulação ambiental deve ser entendida como qualquer medida ou conjunto de medidas adotado pelo Estado receptor do investimento estrangeiro com a finalidade de proteger o meio ambiente.
} 
pagamento de tributos ou multas. A propriedade pode ser confiscada ou sujeita a restrições, ainda, em momentos de conturbação ou de guerra (NEWCOMBE, 2005, p. 23).

Quanto às medidas de regulação adotadas para assegurar a ordem pública e a moralidade, é difícil de determinar seu âmbito de aplicação a fim de definir sua legitimidade, uma vez que os conceitos de ordem pública e moralidade variam de acordo com cada ordenamento jurídico interno. Desse modo, para que a regulação baseada em garantia da ordem pública ou moralidade seja considerada legítima e não suscetível ao pagamento de compensação, deve-se observar os padrões mínimos internacionais de proteção a esses interesses, como as obrigações internacionais de defesa dos direitos humanos, por exemplo (NEWCOMBE, 2005, p. 24).

No que diz respeito à regulação para proteger a saúde humana ou o meio ambiente, não existe jurisprudência tratando acerca da legitimidade da medida, apenas alguns casos antigos que não condizem com o atual disciplinamento da regulação. As autoridades internacionais, no entanto, têm reconhecido a necessidade do Estado de adotar determinadas medidas regulatórias de modo a proteger o meio ambiente. Por exemplo, em 1894 autoridades brasileiras destruíram vários lotes de melancias em razão de um surto de cólera, o que gerou os pedidos de produtores dos Estados Unidos ao seu governo para representá-los no seu requerimento de compensação. O governo estadunidense rejeitou os pedidos dos investidores sob o fundamento de que a medida adotada pelas autoridades brasileiras foi justificável diante das circunstâncias, e nenhuma compensação seria devida (NEWCOMBE, 2005, p. 25).

Embora os parâmetros de legitimidade de uma medida regulatória ambiental não sejam precisos nos instrumentos internacionais de investimento, bem como a jurisprudência não seja satisfatória nesse sentido, é possível identificar alguns fatores que justificam a não configuração de uma medida de regulação ambiental como expropriatória. Jorge Viñuales aponta quatro elementos que indicam que a regulação ambiental não configura, em princípio, uma medida expropriatória: a extensão da privação; o uso da doutrina dos police powers; a relevância do propósito e o impacto de garantias específicas.

O primeiro fator diz respeito ao aspecto prático de que as medidas de regulação ambiental contestadas pelos investidores não foram consideradas equiparáveis à expropriação em razão da ausência de privação substancial do seu direito de propriedade. Ao analisar uma disputa envolvendo essa questão, o primeiro ponto enfrentado pelo tribunal é determinar a extensão de propriedade afetada necessária para que esteja configurada uma privação substancial da propriedade. Os tribunais têm estabelecido como parâmetros para definir uma privação substancial da propriedade o investimento utilizado para fixar a jurisdição e as conexões entre diversos bens do investidor no território do Estado receptor (VIÑUALES, 2012, Seção 12.4.2.1).

Esses parâmetros têm sido adotados no julgamento de diversas controvérsias, por exemplo, no caso Chemtura vs. Canadá, em que o investidor impugnou a medida de uma agência ambiental canadense que suspendeu a autorização para produção e comercialização de um pesticida. Ao averiguar o investimento que estabeleceu a jurisdição, o tribunal argumentou que, enquanto o investimento total realizado pela empresa foi considerado expropriado pelo investidor, e, portanto, ensejou a disputa, apenas uma parte limitada do investimento havia sido comprometida, o que significa que não houve uma privação substancial da propriedade. Além disso, o tribunal entendeu que, da mesma forma que as conexões dos diversos bens do investidor no território do Estado receptor devem ser considerados para precisar os prejuízos da expropriação, tais conexões também devem ser levadas em consideração para determinar a extensão da privação (VIÑUALES, 2012, Seção 12.4.3.3).

Sendo assim, a partir do momento em que se define a extensão necessária da privação da propriedade para que esta seja considerada substancial, os tribunais passam a analisar se a medida regulatória efetivamente resultou na privação substancial. Para tanto os tribunais utilizam critérios como o controle do investimento, a interferência do Estado receptor nas operações relativas ao investimento e a duração dessa interferência (VIÑUALES, 2012, Seção 12.4.2.1).

O segundo fator indicativo de que a regulação ambiental não configura, prima facie, uma medida expropriatória é o reconhecimento da já mencionada doutrina dos police powers, a qual teve origem em duas fontes distintas - na prática estadunidense e no Direito Internacional. Nos Estados Unidos, a doutrina surgiu como uma implicação necessária da obrigação do Estado de proteger a ordem pública, como no caso da proibição da produção e venda de bebida alcoólica decretada pelo país em 1926. Nesse exemplo, houve um con- 
siderável prejuízo aos direitos de propriedade, porém o governo estadunidense, fazendo uso da doutrina dos police powers, alegou que a medida não poderia ser contestada (VIÑUALES, 2012, Seção 15.1.1).

Na Seção 197(1)(a) do Restatement Second of The Foreign Relations Law of United States, excepciona-se do dever de compensação a medida estatal prejudicial ao investidor que seja razoavelmente necessária para a manutenção da ordem pública, segurança e saúde. Na Seção 712, Comentário (g), do Restatement Third of The Foreign Relations Law of United States, reafirma-se a ausência de responsabilidade estatal por medida que afete os direitos de propriedade se resultante de tributação de boa-fé, regulação, confisco por crime ou outro ato semelhante inerente ao poder de polícia do Estado. O Harvard Draft, em seu Artigo 10(5), reconhece a legitimidade de uma medida prejudicial ao investimento se necessária à execução de legislação tributária; se resultante de uma mudança geral no valor cambial; se proveniente da ação de autoridades competentes para manutenção da ordem pública, saúde ou moralidade; se decorrente do exercício válido de direitos beligerantes e se incidental à operação normal das leis do Estado (VIÑUALES, 2012, Seção 15.1.1).

A doutrina dos police powers também teve como fonte o Direito Internacional, a partir do qual esteve associada à expropriação não passível de compensação. Foram elaboradas, no âmbito do Direito Internacional, diversas exceções à regra de que a expropriação enseja o pagamento de compensação pronta, adequada e efetiva, tais como medidas fiscais, ações de proteção à saúde pública e à moralidade, e outras derivadas do legítimo exercício do poder de polícia estatal. Vale ressaltar que, embora a doutrina tenha surgido nessa vertente como justificativa para exclusão do dever do Estado de compensar, o exercício do poder de polícia pelo Estado receptor não simplesmente o isenta de compensar o investidor, mas sim elimina o próprio caráter expropriatório da medida estatal (VIÑUALES, 2012, Seção 15.1.1).

A doutrina dos police powers foi utilizada para justificar a legitimidade de uma política pública de proteção ambiental, por exemplo, no já citado caso Chemtura vs. Canadá. A empresa Chemtura recorreu à Corte Permanente de Arbitragem em razão de medidas de proibição do pesticida lindano e do cancelamento dos registros da substância, tomadas pela Agência Reguladora de Gerenciamento de Pestes canadense (PMRA), por questões ambientais e sanitárias. ${ }^{4}$

Segundo a Corte Permanente de Arbitragem, nesse caso, as medidas adotadas pela PMRA e contestadas pela Chemtura constituíram um exercício válido do poder de polícia (police powers) do Estado canadense. A PMRA tomou essas medidas dentro de sua esfera de competência, de forma não discriminatória e motivada pela preocupação acerca dos perigos ocasionados pelo lindano à saúde humana e ao meio ambiente. Uma medida adotada nessas circunstâncias, de acordo com a decisão arbitral, corresponde ao exercício válido do poder de polícia estatal e, portanto, não caracteriza expropriação. ${ }^{5}$

Além do uso da doutrina dos police powers, o terceiro fator que demonstra o caráter legítimo e não expropriatório da regulação ambiental é a relevância de seu propósito. Caso a medida possua mais de um objetivo, deve ser considerado o seu principal propósito a fim de identificar se a medida é legítima ou não. Diversos acordos internacionais sobre investimento ou comércio possuem dispositivos que excepcionam as obrigações constantes no acordo quando a regulação busca um propósito ambiental. Exemplo disso é o já citado Artigo 4o(b) do Anexo B do Modelo de BIT dos Estados Unidos, na sua versão de 2012, que afirma que, salvo em situações excepcionais, medidas regulatórias não discriminatórias adotadas para proteger interesses públicos legítimos, como a saúde pública, a segurança e o meio ambiente, não constituem expropriação indireta (VIÑUALES, 2012, Seção 12.4.2.3).

O propósito da medida de regulação ambiental também pode ser considerado parâmetro de sua legitimidade sob o aspecto de compor o risco comercial assumido pelo investidor. Se a medida é adotada com o objetivo de proteger o meio ambiente, é improvável que o investidor consiga sustentar que esta não faça parte da regulação normal que compõe o risco comercial (VIÑUALES, 2012, Seção 12.4.2.3).

\footnotetext{
Disputa sob as regras da Uncitral e administrada pela Corte Permanente de Arbitragem, cuja decisão final de 2010 pode ser encontrada em: https://www.italaw.com/sites/default/files/case-documents/ita0149_0.pdf. Acesso em: 10 de junho de 2020.

5 Ver parágrafo 266 da decisão final do caso Chemtura vs. Canadá disponível em: https://www.italaw.com/sites/default/files/case-documents/ita0149_0.pd. Acesso em: 10 jun. 2020.
} 
Tal fator pode ser visualizado, ainda, sob o ponto de vista do impacto do objetivo da medida de regulação ambiental no sentido de avaliar sua proporcionalidade. Por exemplo, na disputa Tecmed vs. México, o Tribunal considerou que a intenção do governo é menos importante que os efeitos da medida, e a submeteu a um teste de proporcionalidade, em que se verificou a relação entre os meios empregados e o objetivo almejado pela medida (VIÑUALES, 2012, Seção 12.4.2.3).

A referida disputa ocorreu em torno de uma medida adotada pelo Instituto Nacional Ecológico (INE), órgão mexicano, que rejeitou a renovação da licença da Tecmed para operação de um aterro adquirido pela empresa em um leilão público. $O$ tribunal arbitral entendeu que houve outros fatores que motivaram a expedição da mencionada medida que não o descumprimento de condições da licença ou a legislação ambiental mexicana, e que tiveram um efeito decisivo na rejeição da renovação da licença. Esses fatores estavam ligados a circunstâncias sociais e políticas e à pressão exercida sobre as autoridades governamentais. Nesse viés, a Corte Arbitral não visualizou a proporcionalidade entre a medida do INE e os supostos fundamentos que a motivaram, uma vez que não restou caracterizado o risco presente ou iminente no equilíbrio ecológico ou na saúde. ${ }^{6}$

De maneira geral, os governos possuem uma margem de apreciação para determinar políticas de interesse público. Para evitar o abuso desse poder estatal de discricionariedade, os tribunais têm aplicado um teste a fim de verificar se a medida adotada é razoável e proporcional ao objetivo almejado. Há casos julgados na Corte Europeia de Direitos Humanos e nas Cortes dos Estados Unidos que consideram, como parâmetros para o teste de proporcionalidade, se a medida está fundamentada em evidências científicas sólidas ou se a medida é mais severa que o necessário para atingir a finalidade legítima (KOLO; WÄLDE, 2001, p. 828).

Vários elementos são ponderados quanto à proporcionalidade da medida de acordo com os tribunais, porém todos visam a garantir que o Estado não exceda o seu poder regulatório. Esse teste de proporcionalidade objetiva não só assegurar um equilíbrio entre o direito de propriedade do investidor e o interesse público resguardado pelo Estado receptor, mas também impedir que o Estado desvirtue seu poder para fins políticos ou econômicos (KOLO; WÄLDE, 2001, p. 830).

O último fator levado em consideração para analisar se uma regulação ambiental é expropriatória ou não é o de averiguar se o investidor recebeu garantias específicas do Estado receptor de que tal regulação não ocorreria. No caso Methanex vs. Estados Unidos, o Tribunal estabeleceu como exceção à doutrina dos police powers a garantia de compromissos específicos ao investidor estrangeiro de que o Estado abdicaria do exercício de seu poder de regulação (VIÑUALES, 2012, Seção 12.4.2.4).

A referida disputa envolveu a medida de proibição da venda e utilização do aditivo MTBE por parte do Estado da Califórnia, justificada pelo risco de tal produto ao meio ambiente. A Corte Arbitral reconheceu que a medida adotada pela Califórnia configurava uma regulação não discriminatória para alcançar um objetivo público e em conformidade com o devido processo, a qual não caracterizaria expropriação nem seria passível de compensação, salvo se presente uma garantia específica pelo Estado receptor. ${ }^{7}$

A controvérsia que circunda essa questão diz respeito a que tipo de garantia específica deve ser considerado apto a impedir a adoção de medida regulatória pelo Estado receptor sob pena de esta configurar como medida expropriatória suscetível ao pagamento de compensação. Na disputa Methanex vs. Estados Unidos foram identificados cinco requisitos para que um compromisso firmado pelo Estado receptor constitua uma garantia específica: 1) a garantia deve ter sido conferida pelo próprio governo regulador, e não por uma agência diversa do governo; 2) a garantia deve ter sido dada ao próprio investidor, e não a qualquer investidor em potencial; 3) a garantia deve ter sido concedida no momento em que o investidor está avaliando sua entrada no mercado de modo que fique claro que ele considerou o compromisso assegurado na sua decisão de investir; 4) a garantia deve ter sido específica, não podendo abranger qualquer tipo de regulação, mas apenas a uma regulação específica e 5) a garantia deve ter sido dada por uma autoridade de boa-fé (VIÑUALES, 2012, Seção 15.1.4).

\footnotetext{
6 Ver parágrafos 127, 132, 148 e 149 da decisão final de 2003 da disputa submetida ao ICSID disponível em: https://www.italaw.com/sites/ default/files/case-documents/ita0854.pdf. Acesso em: 10 jun. 2020.

Ver parágrafo 7으, Part IV, Capítulo D da decisão final de 2005 da disputa, realizada de acordo com as regras da Uncitral e administrada pelo Icsid, que se encontra disponível em: https://www.italaw.com/sites/default/files/case-documents/ita0529.pdf. Acesso em: 10 jun. 2020.
} 
$\mathrm{Na}$ análise do caso Methanex vs. Estados Unidos, o Tribunal Arbitral concluiu que não houve qualquer garantia dada pelo governo à empresa, a qual entrou em um ambiente político-econômico amplamente conhecido por suas instituições de proteção ambiental e sanitária em níveis federal e estadual, bem como de outros atores sociais vigilantes acerca do impacto de compostos químicos e da sua usual restrição em virtude de aspectos ambientais e de saúde. A empresa Methanex estava, portanto, ciente de todas circunstâncias e não entrou nesse mercado em razão de qualquer compromisso firmado pelo governo. ${ }^{8}$

Além dos citados fatores apontados por Viñuales (extensão da privação, uso da doutrina dos police powers, relevância do propósito e impacto de garantias específicas), a eventual natureza discriminatória da medida estatal também deve ser considerada para fins de análise de ocorrência de expropriação do investimento. O princípio da não discriminação é uma garantia constante na grande maioria dos acordos internacionais de investimento e se expressa por meio da cláusula do tratamento nacional. De forma geral, a garantia proíbe que o Estado dispense um tratamento ao investidor estrangeiro distinto do concedido aos seus nacionais. Dessa maneira, o tratamento distinto quanto a, por exemplo, uma medida regulatória, não pode estar fundamentado no fato de o investidor ser estrangeiro, mas apenas se houver um motivo legítimo que justifique a discriminação. $O$ reconhecimento da discriminação normalmente leva à constatação de que a medida foi expropriatória, bem como interfere no quantum compensatório em virtude da expropriação (KOLO; WÄLDE, 2001, p. 836-837).

Em síntese, os acordos sobre investimentos e a prática das cortes arbitrais sobre investimento têm mostrado que a regulação ambiental normalmente enquadra-se na esfera de situações excepcionais que autorizam o Estado receptor a tomar medidas que, em circunstâncias normais, seriam consideradas expropriatórias e passíveis de compensação. De maneira geral, os principais argumentos que ratificam esse entendimento, em princípio, são o legítimo exercício do poder de polícia estatal (doutrina dos police powers), a importância do propósito almejado pela medida regulatória e a ausência de caráter discriminatório da medida. É essencial verificar no caso concreto, portanto, a real finalidade da medida, que deve corresponder a um interesse público legítimo relevante e ser adotada de forma não discriminatória, observado o devido processo, e proporcional ao objetivo pretendido.

Sendo assim, é possível perceber que a regulação ambiental, em princípio, não configura uma medida expropriatória. Isso posto, os dispositivos normalmente constantes em acordos internacionais de investimento, relativos aos requisitos de legitimidade de uma expropriação indireta, entre eles o pagamento de compensação ao investidor, não seriam aplicáveis à medida regulatória legítima.

Os tribunais arbitrais, quando suscitada a controvérsia sobre o caráter expropriatório de uma medida, têm deixado claro que há uma distinção entre uma regulação legítima e uma expropriação, ainda que indireta. Enquanto os requisitos para a legitimidade de uma expropriação indireta geralmente são claros nos acordos internacionais de investimento, os critérios para distinguir uma medida de regulação legítima, não passível de pagamento de compensação, de uma medida expropriatória, não estão expressos nos acordos.

É comum que os textos dos acordos de investimento garantam o direito do Estado receptor de adotar medidas para a proteção de interesses públicos relevantes sem que sejam consideradas expropriatórias. Os acordos, todavia, não delimitam as hipóteses nem os termos em que isso pode ocorrer, deixando para as instâncias decisórias a interpretação acerca dos parâmetros que ensejam uma regulação legítima, o que pode gerar uma inconsistência quanto ao disciplinamento do tema na esfera do Direito Internacional.

Dessa maneira, percebe-se que não há uma linha precisa entre o conceito de expropriação indireta e medidas regulatórias ambientais não suscetíveis à compensação. Há, em resumo, critérios encontrados nas disputas solucionadas em tribunais e sintetizados por autores especialistas no tema para distinguir as duas situações, já abordados neste tópico: a) o grau de interferência da medida no direito de propriedade do investidor; b) o caráter da medida estatal, que inclui seu propósito e o contexto de sua adoção e c) a interferência da medida nas expectativas razoáveis e legítimas do investidor (OECD..., 2004, p. 22).

\footnotetext{
8 Ver parágrafos 9o e 10으, Parte IV, Capítulo D da decisão final da disputa disponível em: <https://www.italaw.com/sites/default/files/case-documents/ita0529.pdf>. Acesso em: 10 de junho de 2020.
} 
A partir desses parâmetros, é possível visualizar que uma regulação ambiental legítima deve reunir os seguintes elementos: 1) deve ser proporcional e necessária para servir a um propósito público; 2) deve ser não discriminatória na lei e na prática e 3) não deve violar um acordo ou uma expectativa legítima do investidor, embora seja reconhecido que a regulação ambiental constitui um exercício legítimo do poder de polícia estatal (KOLO; WÄLDE, 2001, p. 827).

\section{CONSIDERAÇÕES FINAIS}

O artigo buscou demonstrar os parâmetros encontrados no Direito Internacional do Investimento para que uma medida adotada por um Estado receptor, com vistas à proteção do meio ambiente, esteja enquadrada como uma regulação ambiental legítima ou uma medida expropriatória, suscetível a pagamento de compensação ao investidor estrangeiro.

O texto partiu do seguinte problema: os acordos internacionais de investimento não determinam em que situações uma medida de regulação adotada pelo Estado receptor será considerada uma expropriação, ainda que indireta, ou uma regulação legítima, que não enseja o dever do Estado receptor de indenizar o investidor estrangeiro.

Em razão disso, o artigo pretendeu responder às seguintes perguntas: 1) Em que hipóteses a atuação estatal que interfere no investimento estrangeiro será considerada uma expropriação indireta ou uma regulação legítima?, 2) A regulação estatal, ainda que legítima, enseja o dever de compensação ao investidor por parte do Estado receptor?, 3) A prática de políticas públicas ambientais pode ser considerada uma regulação legítima?

Na primeira seção, observou-se a definição de expropriação encontrada nos acordos internacionais de investimento. A partir daí, esboça-se a noção de expropriação indireta, que, de forma geral, pode ser definida como uma medida ou um conjunto de medidas que retira de forma substancial o aproveitamento econômico de um investimento, sem que, contudo, seja retirado o título formal de propriedade do investidor.

Na segunda seção traçam-se os principais critérios para se distinguir entre uma medida de expropriação indireta e uma medida de regulação legítima. Os parâmetros mais utilizados na prática do Direito Internacional do Investimento são os seguintes: o impacto econômico da medida; a interferência da medida na expectativa legítima do investidor e a natureza, o objetivo e o caráter da medida, que podem ser traduzidos em sua boa-fé, em seu propósito público legítimo e a sua característica não discriminatória respectivamente.

Na terceira seção avaliam-se as circunstâncias em que uma medida de regulação ambiental estaria inserida no contexto de legitimidade de modo a não ser considerada expropriatória nem gerar o dever do Estado receptor de indenizar o investidor. Diversos são os parâmetros para que uma medida de regulação ambiental seja considerada legítima sob o prisma do Direito Internacional do Investimento, tais como a doutrina dos police powers, reflexo do poder de polícia estatal; a relevância do propósito pretendido pela medida, que enseja um teste de proporcionalidade entre o objetivo e o efeito da medida; a ausência de garantias específicas para o investidor estrangeiro por parte do Estado receptor, que revela a ausência de expectativa legítima do investidor; e o caráter não discriminatório da medida.

Após a explanação desses fatores ao longo do artigo, é possível reconhecer que os acordos internacionais de investimento não estabelecem critérios distintivos claros entre uma expropriação indireta e uma regulação legítima, delegando tal tarefa para as Cortes Arbitrais. Diante disso, gera-se uma inconsistência no Direito Internacional do Investimento acerca dos requisitos que devem ser reunidos para que uma medida regulatória voltada à proteção ambiental seja considerada uma regulação legítima, não passível de pagamento de compensação ao investidor.

\section{REFERÊNCIAS}

DOLZER, Rudolf; SCHREUER, Christoph. Principles of International Investment Law. Oxford University Press, 2008.

FONSECA, Karla Closs. Investimentos estrangeiros: regulamentação internacional e acordos bilaterais. Curitiba: Juruá, 2010.

JACINTO, Justin; MOLOO, Rahim. Environmental and Health Regulation: Assessing Liability Under Investment Treaties. Berkeley Journal of International Law, v. 29, p. 1-65, 2011. 


\section{Direito自 \\ Debate}

KOLO, Abba; WÄLDE Thomas. Environmental Regulation, Investment Protection and "Regulatory Taking". International Law, 50 INT'L \& COMP. L.Q., p. 811-848, 2001.

NEWCOMBE, Andrew. The Boundaries of Regulatory Expropriation in International Law. ICSID Review - FILJ, 20, p. 1-50, 2005.

OECD. Organization for Economic Cooperation and Development. "Indirect Expropriation" and the "Right to Regulate". In: International Investment Law, OECD Working Papers on International Investment, OECD Publishing, 2004/04.

POTESTÀ, Michele. Legitimate Expectations in Investment Treaty Law: Understanding the Roots and the Limits of a Controversial Concept. Society of International Economic Law (SIEL), 3rd Biennial Global Conference, 2012.

RIBEIRO, Marilda Rosado de Sá. Expropriação: revisitando o tema no contexto dos estudos sobre investimentos estrangeiros. In: RIBEIRO, Marilda Rosado de Sá (org.). Direito Internacional dos Investimentos. Rio de Janeiro: Renovar, 2014. p. 127-158.

SORNARAJAH, M. The international law on foreign investment. Cambridge: Cambridge University Press, 2010.

UNCTAD. United Nations Conference on Trade and Development. Expropriation: UNCTAD Series on Issues in International Investment Agreements II. New York; Geneva: United Nations, 2012.

UNCTAD. United Nations Conference on Trade and Development. UNCTAD's Reform Package for the International Investment Regime. New York; Geneva: United Nations, 2018.

VIÑUALES, Jorge E. Foreign Investment and the Environment in International Law. Cambridge: Cambridge University Press, 2012. Edição Kobo. 